\title{
Acidity variations along hydrological processes of snow deposit, snowmelt and runoff.
}

\author{
N. Ishikawa, H. Narita, Y. Ishii and Y. Kodama. \\ (Hokkaido University, Sapporo, 060, Japan)
}

\begin{abstract}
Assessment of the acidification and changes of the chemical contents of seasonal snow within the snowmelt process were carried out in northern Hokkaido, Japan. The range of $\mathrm{pH}$ in the dry snow was 4.7 to 5.3 and $\mathrm{EC}$ was 11 to $56 \mu \mathrm{S} / \mathrm{cm}$. These values were similar to those of the snow accumulated on the forest floor and the canopy. Horizontal distributions of $\mathrm{pH}$ in snow cover were found to be homogenous. However, once melt water penetrated, the homogenous distributions were partly destroyed even in winter. During the snowmelt period $\mathrm{pH}$ of the snow increased and EC decreased to below $10 \mu$ $\mathrm{S} / \mathrm{cm}$. $\mathrm{pH}$ of the melt water that percolated through $10 \mathrm{~cm}$ deep soil accounted for 6.4 to 5.8 , and those of the stream 7.1 to 6.8. The values did not change much through the snowy season. The percolated water showed high concentrations of $\mathrm{SO}_{4}{ }^{2-}$ and $\mathrm{NO}_{3}{ }^{-}$compared with those of snow, but the water contained higher $\mathrm{Ca}^{2+}$ concentrations, which neutralized the anion, and $\mathrm{pH}$ of the water increased.
\end{abstract}

Key words: acidity, snowmelt, runoff, anion, electric conductivity

\section{Introduction}

Pollutants emitted into the air from fossil combustion such as exhaust gas from automobiles and various industrial manufacturing processes are removed by rainfall (snowfall) or gravitational fallout. Cleansing of the air results in deposition of pollutants on the earth surface, soil and water reservoirs. There are many studies of acid rain and the influences on the ecosystem. In snowy regions chemical constituents in snow stay on the ground surface or forest canopy for a long time during cold periods and subsequently run off into rivers or lakes in a short time at snowmelt season, which sometimes induces a rapid depression of pH of river water ( Ishii et al, 1992, Suzuki, 1982, Johannessen and Henrikson, 1978). Therefore, acidity of snow has been recognized as an important factor in environmental problems. However, there is little information about the changes of $\mathrm{pH}$ and chemical contents within the snowmelt process (Suzuki, 1991), or the effects of the forest on the chemistry of snow (Jones, 1988). The objectives of this paper are to assess the change of acidification and chemical contents of seasonal snow within the processes of snow deposit, snowmelt and runoff.

\section{Observation site and method}

The measurements of acidity $(\mathrm{pH})$, electric conductivity $(\mathrm{EC})$ and chemical constituents of snow, melt water and river water were carried out from 1994 to 1996 and include two snow cover seasons at a small watershed located within the Moshiri Basin $\left(142^{\circ} 17^{\prime} \mathrm{E}, 44^{\circ} 22^{\prime} \mathrm{N}\right)$ northern Hokkaido, Japan. The basin is one of the coldest areas in Japan, with an annual mean air temperature of $3.5^{\circ} \mathrm{C}$. In winter, the basin is covered with $2-3 \mathrm{~m}$ depth of snow, and a daily minimum air temperature below $-20^{\circ} \mathrm{C}$ occurs 
frequently. However, the temperature at the bottom of the snow cover stays at $0{ }^{\circ} \mathrm{C}$ and continuous runoff is maintained (Kojima and Motoyama, 1985). Vegetations at the watershed are mixed forests of evergreen needle-leaf trees and deciduous broad-leaved trees with bamboo bush undergrowth. The surface soil is composed primarily of silt and clay, and is underlain to a depth of $3 \mathrm{~m}$ by tuffaceous silt stone and sandstone of the Neocene (Kobayashi at al, 1995). Snow samples were taken from three fixed sites (open site, forest floor, forest canopy) near the outlet of the watershed 7 to 8 times during the snow season. . Also, water samples were obtained from the bottom of the snow cover, from soil $10 \mathrm{~cm}$ deep and from the stream. After the snow samples had been transferred to uncontaminated polyethylene bags and water samples were contained in polyethylene bottles, $\mathrm{pH}$ and $\mathrm{EC}$ were measured using a $\mathrm{pH}$ potentiometer with a glass electrode and a portable conductometer. Anions and cations were determined by an ion chromatography (DIONEX-2000i/SP).

\section{Results and Discussion}

Monthly variations of $\mathrm{pH}$ and $\mathrm{EC}$ of snow at three sites are shown in Table 1. The intercepted snow on the canopy had fallen off completely by the end of March. $\mathrm{pH}$ of the snow at the open site was in the range of 4.7 to 5.3 , and EC was 11 to $56 \mathrm{\mu S} / \mathrm{cm}$ until March when
Table 1:pH and EC of snow cover at three sites

\begin{tabular}{|c|c|c|c|c|c|c|}
\hline \multirow[t]{2}{*}{ Date } & Nov. 15 & Dec 20 & Jan 19 & Feb 21 & Kar. 29 & dpr. 25 \\
\hline & pH $\quad E C$ & pH EC & $\mathrm{pH} \quad \mathrm{EC}$ & $E C$ & $E C$ & $\mathrm{pH}$ \\
\hline R surf. & 4.99 & $4.9 \quad 15$ & 4.811 & 4.73 & 6.0 & 5.63 \\
\hline mean & $4.8 \quad 55$ & 5.124 & 4.822 & $4.8 \quad 18$ & 5.5 & $5.2 \quad 12$ \\
\hline F surf. & 5.032 & $5.3 \quad 35$ & 4.816 & 4.920 & $5.6 \quad 28$ & 5.319 \\
\hline mean & $4.9 \quad 28$ & $5.0 \quad 26$ & $5.0 \quad 34$ & $5.1 \quad 25$ & $5.3 \quad 18$ & $5.4 \quad 16$ \\
\hline L & 5.143 & $\begin{array}{ll}5.1 & 31\end{array}$ & 4.726 & 4.728 & $x$ & $x$ \\
\hline
\end{tabular}
no snowmelt occurred. During the snowmelt period, $\mathrm{pH}$ increased significantly and EC decreased below $10 \mu \mathrm{S} / \mathrm{cm}$. The values are similar to those of snow of the forest floor and canopy. Snow cover showed a layered structure, so it can be assumed that $\mathrm{pH}$ and $\mathrm{EC}$ of each layer indicates the values of snowfall when the layer formed. Figure 1 shows homogeneous distributions of $\mathrm{pH}$ in the lateral, and the $\mathrm{pH}$ of the respective layers kept the original values as long as snow was dry. The dominant $\mathrm{pH}$ of the whole snow is 5.0 to 5.5. Even in mid-winter, snowmelt occurred by temporary warm weather. Traces of melt water penetration were seen as ${ }^{150} \quad$ Feb. 21 layered ice or by the vertical structure of granular snow, which were different from the compacted snow nearby, and the laterally homogeneous : distributions of $\mathrm{pH}$ were partly destroyed. After snowmelt began $\mathrm{pH}$ is near the surface increased at first and then the $\mathrm{pH}$ of the whole snow rose to above 6.0. Some chemical

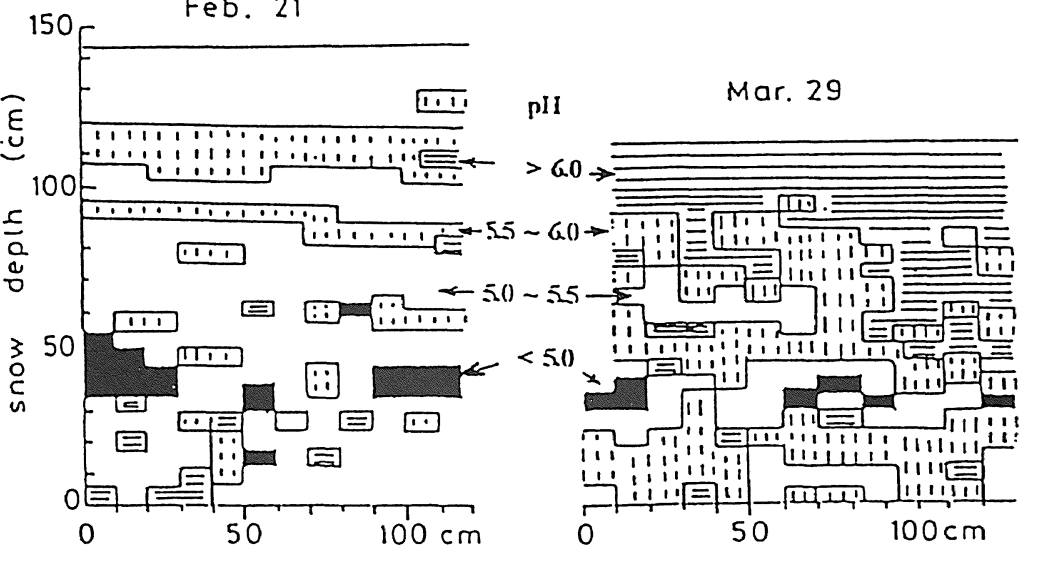
constituents were measured at the same time, whose distributions for the two periods showed the same pattern as $\mathrm{pH}$, namely; a laterally the homogeneous distribution when the snow was dry, but which was 
destroyed by melt water percolation. Figure 2 shows ratios of $\mathrm{SO}_{4}{ }^{2-}$ and $\mathrm{Na}^{+}$at three different times. The concentrations of both ions change drastically during the snowmelt period and the amounts in April decreased below $40 \%$ of mid-winter.

Comparisons of $\mathrm{pH}$ at different sites are seen in Fig.3. pH of snow at the forest has a similar value to the open site. $\mathrm{pH}$ of meltwater under $10 \mathrm{~cm}$ deep soil was 6.4 to 5.8 , and of the stream was 7.1 to 6.8 , which means the soil had a moderating influence on the acidity of the meltwater. Variations of EC are also shown in the figure. The surface snow exhibited a smaller value (less than $10 \mu \mathrm{S} / \mathrm{cm}$ ) during the season. EC of the whole snow was high in November and decreased during the snowmelt period, while the meltwater that percolated through $10 \mathrm{~cm}$ of soil carried

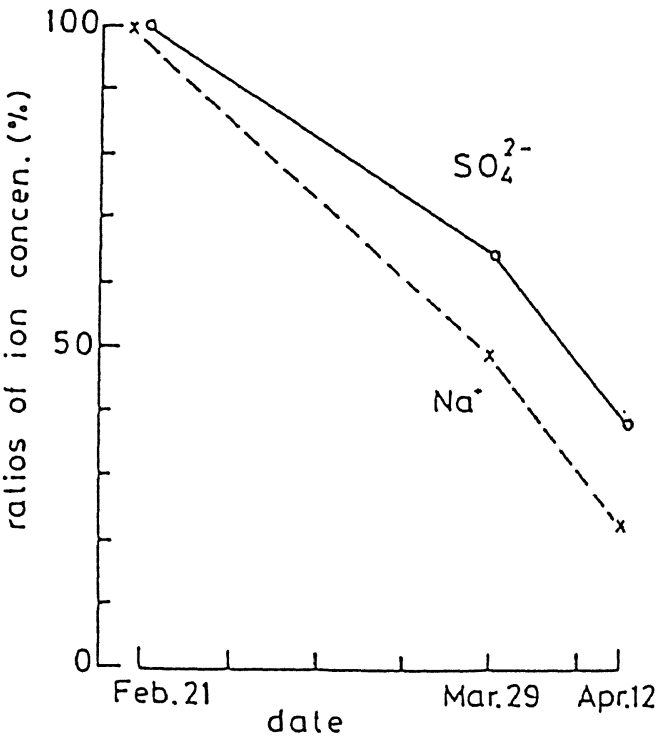

Fig.2 Changes of $\mathrm{SO}_{4}{ }^{2-}$ and $\mathrm{Na}^{+}$ higher EC such as 40 to $50 \mu \mathrm{S} / \mathrm{cm}$ and 70 to $80 \mu \mathrm{S} / \mathrm{cm}$ to the stream.

Assuming the neutral condition of an ion, the ion balance of snowmelt water is expressed by the following equation (Ishii and Kobayashi, 1996), $\left[\mathrm{H}^{+}\right]+\left[\mathrm{Na}^{+}\right]+\left[\mathrm{NH}_{4}{ }^{+}\right]+\left[\mathrm{K}^{+}\right]+\left[\mathrm{Ca}^{2+}\right]+\left[\mathrm{Mg}^{2+}\right]=\left[\mathrm{Cl}^{-}\right]+\left[\mathrm{NO}_{3}{ }^{-}\right]+\left[\mathrm{SO}_{4}{ }^{2-}\right]+\left[\mathrm{HCO}_{3}{ }^{-}\right]$

The main chemical constituents from human activity are $\mathrm{NO}_{3}^{-}, \mathrm{SO}_{4}^{2-}, \mathrm{Ca}^{2+}$ and $\mathrm{NH}_{4}{ }^{+}$ However, $\mathrm{SO}_{4}{ }^{2-}$ and $\mathrm{Ca}^{2+}$ include not only those artificially made but also those from sea salt origin. So we should evaluate only the non sea salt origin of $\mathrm{SO}_{4}{ }^{2+}\left(\mathrm{nss} \mathrm{SO}_{4}{ }^{2-}\right)$ and $\mathrm{Ca}^{2+}\left({ }_{\mathrm{nss}} \mathrm{Ca}^{2+}\right)$ for considering the acidity of water. Monthly variations of $\mathrm{pH}$ and chemical constituents of snow at three sites and water from December to April in Fig.4, where all ions are expressed in $\mu$ eq/l. Snow cover at three sites contained $\mathrm{NO}_{3}{ }^{-}$, $\mathrm{SO}_{4}{ }^{2-}$ and $\mathrm{NH}_{4}{ }^{+}$all the time but non $\mathrm{Ca}^{2+}$, resulted low $\mathrm{pH}$ of snow. The water percolated

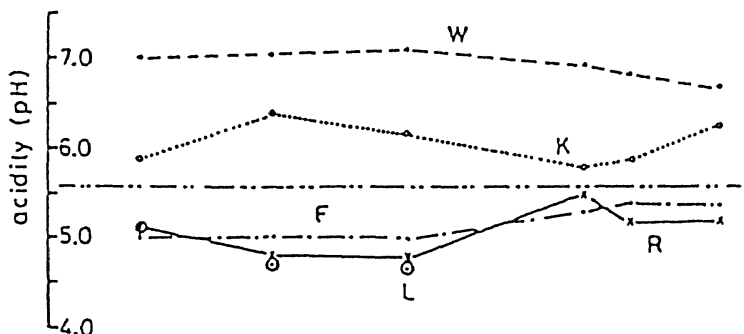
through soil and stream water showed high concentrations of $\mathrm{SO}_{4}{ }^{2-}$ and $\mathrm{NO}_{3}{ }^{-}$compared with snow, but they contained high $\mathrm{Ca}^{2+}$, which neutralized the anions and the $\mathrm{pH}$ of the water increased. In this observation, carbonates in the water are not measured, but their importance is pointed out by Ishii (1996) and O'Brien et al. (1993). So it is necessary to consider the role of dissolved carbonate in the stream water.

\section{Conclusion}


Observations of the acidification and chemical constituents of seasonal snow within the snowmelt process were carried out at Moshiri Basin, Japan. pH of dry snow at the open site was in the range 4.7 to 5.3 , which is similar to the snow accumulated on the forest floor and the canopy. Dry snow has laterally homogenous distributions of $\mathrm{pH}, \mathrm{EC}$ and chemical constituents of each layered structure. However, the melt water percolation destroyed the homogeneous distribution. Meltwater showed higher $\mathrm{pH}$ such as 5.8 to 6.4

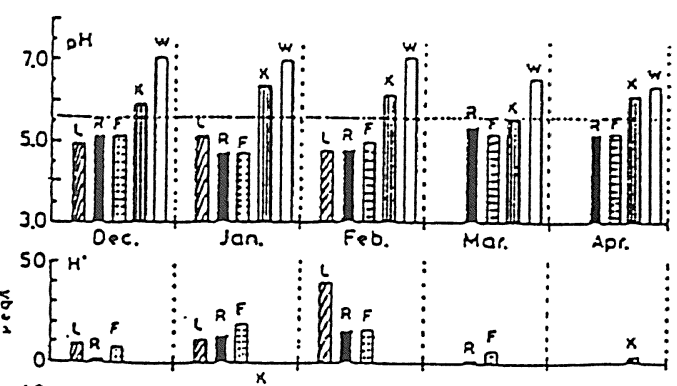

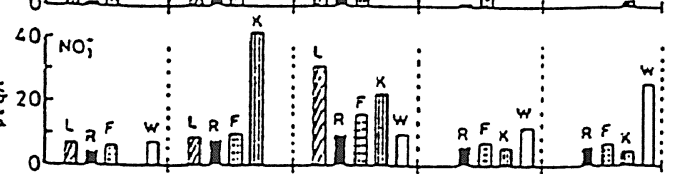
for the water percolated through only $10 \mathrm{~cm}$ soil and 6.8 to 7.1 for the stream water. It contained high $\mathrm{Ca}^{2+}$, which neutralized anions and increased the $\mathrm{pH}$ of the water.

\section{Acknowledgements}

The authors are indebted to the staff of Moshiri Branch at the Uryu Experimental Forest, Hokkaido University for their logistic support. A part of this research was supported by the scientific research fund from the Ministry of Education, Culture and Science of Japan.

\section{Reference}

Ishii, Y. and Kobayshi, D., 1996: Episodic acidification of stream water caused by snowmelt. Geoph. Bulletin of Hokkaido Univ., 49, 15-24.

Ishii,Y., Suzuki,K., Kodama,Y. and Kobayashi,D., 1992: Snowmelt water runoff in a boreal forest, Eastern Canada. Low Temp. Sci., 51, 77-92.

Johannessen, M. and Henriksen, A., 1978: Chemistry of snow meltwater: Changes in concentration during melting. Water Resour. Res., 14, 615-619.

Jones, H.G., 1988: Nitrate, Sulfate and hydrogen fluxes through a boreal forest snowpack during the spring melt period. Proceedings of the Inter. Assoc. for Theor. and Applied Limnol., 23, 2286-2290.

Kobayshi, D., Kodama, Y., Ishii, Y., Tanaka, Y., and Suzuki, K., 1995: Diurnal variations in stream flow and water quality during the summer dry season. Hydrological Processes. 9, 833-841.

Kojima, K. and Motoyama, H.,1985: Melting and heat exchange at the bottom of a snow cover. Annals of Glaciol., 6, 276-277.

O'Brien, A.K., Rice, K.C., Kennedy, M.M. and Bricker, O.P., 1993: Comparison of episodic acidification of Mid-Atlantic Upland and Coastal Plain streams. Water Resour. Res., 29, 3029-3039.

Suzuki, K., 1991: Diurnal variation of the chemical characteristics of meltwater. Seppyo, 53, 21-31.

Suzuki, K., 1982: Chemical changes of snow cover by melting. Japanese J. Limnol., 43, 102-112. 